Araştırma ve Geliştirme Dergisi

International Journal of

Engineering Research and

Development
UMAGD, (2021) 13(2), 600-611.

10.29137/umagd.878818

Cilt/Volume:13 Sayı/Issue:2 Haziran/June 2021

Araștırma Makalesi / Research Article

\title{
Bir Isı Borusunun Akış ve Isı Transfer Karakteristiklerinin Sayısal Olarak İncelenmesi
}

\section{Numerical Investigation of Flow and Heat Transfer Characteristics of a Heat Pipe}

\author{
Mevlüt Emre Aslantaş ${ }^{1}$ iD, Tolga Demircan ${ }^{1 *}$ iD \\ ${ }^{1}$ Kırıkkale Üniversitesi, Mühendislik Fakültesi, Makine Mühendisliği Bölümü, 71450, Kırıkkale, TÜRKIYYE
}

Başvuru/Received: 12/02/2021

Kabul / Accepted: 08/03/2021

Çevrimiçi Basım / Published Online: 23/05/2021

Son Versiyon/Final Version: 18/06/2021

\section{Öz}

Bu çalışmada 1sıl kontrol uygulamalarında önemli bir yere sahip olan bir 1sı borusunun 1sıl ve akış karakteristikleri incelenmiş̧ir. Isı borusunun yoğuşturucu bölüm ve orta adyabatik bölüm uzunluklarının birbirine oranı $\left(\mathrm{L}_{\mathrm{c}} / \mathrm{L}_{\mathrm{a} 1}\right)$ sirasıyla $0,5,1,1,25$ ve 2 olacak şekilde değiştirilerek dört farklı model geometri oluşturulmuştur. Bu model geometriler için, 1sı girdileri 10W ile 80W arasında, doluluk oranı ise $\% 40$ ile \%80 arasında değiştirilerek Hesaplamalı Akışkanlar Dinamiği aracılığ 1 ile sayısal analizler yapılmıştır. Bu kapsamda, iki fazlı akış yaklaşımı ile zamana bağlı çözümler yapılmış, 1sı borusu içindeki akışın sıcaklık ve hız dağılımları belirlenmiş̧ir. Sonuç olarak bu çalışmada incelenen parametre aralığında, model geometrinin yoğuşturucu kısmının uzunluğunun artırılmasının 1sıl performansı olumlu yönde etkilediği gözlemlenmiştir. Ayrıca farklı doluluk oranları arasında \%50 doluluk oranının optimum ısıl performans sergilediği belirlenmiştir.

\section{Anahtar Kelimeler}

"Isı borusu, Hesaplamalı akışkanlar dinamiği (HAD), İki fazlı akış, Isı Transferi ”

\begin{abstract}
In this study, the thermal and flow characteristics of a heat pipe, which has an important place in thermal control applications, have been investigated. Four different model geometries were created by changing the ratio of the lengths of the condenser section and the middle adiabatic section $\left(\mathrm{L}_{c} / \mathrm{L}_{\mathrm{a}}\right)$ of the heat pipe. This ratio has been changed to be $0.5,1.0,1.25$ and 2.0 . For these model geometries, the heat inputs were changed between $10 \mathrm{~W}$ and $80 \mathrm{~W}$, and the occupancy rate between $40 \%$ and $80 \%$. Numerical analyzes were made through Computational Fluid Dynamics. In this context, time-dependent solutions are made with the two-phase flow approach. The temperature and velocity distributions of the flow in the heat pipe are determined. As a result, it has been observed that increasing the length of the condenser section of the model geometry has a positive effect on the thermal performance in the parameter range examined in this study. In addition, it was determined that 50\% occupancy rate showed optimum thermal performance among different occupancy rates.
\end{abstract}

Key Words

"Heat pipe, Computational Fluid Dynamics (CFD), Two phase flow, Heat transfer" 


\section{Semboller ve Kisaltmalar}

\begin{tabular}{|c|c|}
\hline$A$ & Isl transfer alanı $\left(\mathrm{m}^{2}\right)$ \\
\hline$c_{p}$ & Özgül ısı kapasitesi (J/kg.K) \\
\hline$D$ & Isı borusu çapı (mm) \\
\hline E & $\dot{I}_{c ̧}$ enerji $(\mathrm{kJ} / \mathrm{kg})$ \\
\hline$g$ & Yer çekim ivmesi $\left(\mathrm{m} / \mathrm{s}^{2}\right)$ \\
\hline$L$ & Uzunluk (mm) \\
\hline$P$ & $\operatorname{Basınç~(Pa)~}$ \\
\hline$R$ & Isıl direnç $(K / W)$ \\
\hline$Q$ & $I s l(W)$ \\
\hline$S_{m, b}$ & Buhar kütle kaynak terimi $\left(\mathrm{W} / \mathrm{m}^{3}\right)$ \\
\hline$S_{m, s}$ & Slvı kütle kaynak terimi $\left(\mathrm{W} / \mathrm{m}^{3}\right)$ \\
\hline$S_{h}$ & Gizli ısı kaynă̆ı (kg/m3.s) \\
\hline$t$ & Zaman $(s)$ \\
\hline$T$ & Sicaklık $(K)$ \\
\hline
\end{tabular}

\begin{tabular}{l|l}
$\vec{v}$ & Hiz $(\mathrm{m} / \mathrm{s})$ \\
$\alpha$ & Hacimsel oran \\
$\mu$ & Dinamik viskozite \\
$\rho$ & Yoğunluk \\
$\varepsilon$ & Türbülans kinetik enerjisinin yayılma hızı \\
$k$ & Isl iletim katsaylst \\
& \\
$b$ & Buhar \\
$e f f$ & Efektif \\
$\mathrm{L}_{\mathrm{a}}$ & Adyabatik bölüm uzunluğu \\
$\mathrm{L}_{\mathrm{c}}$ & Yoğuşturucu bölüm uzunluğu \\
$\mathrm{L}_{\mathrm{e}}$ & Buharlaştırıcı bölüm uzunluğu \\
$S$ & Stvı
\end{tabular}

\section{Giriş}

Günümüzde uzay, haberleşme, savunma vb. birçok önemli sektörde, bilgisayar ve benzeri elektronik devre işlemcilerinin 1sıl kontrolünde, iklimlendirme uygulamalarında, güneş kolektörleri gibi alanlarda sıklıkla 1sı boruları kullanılmaktadır. Isı boruları, küçük boyut ve hafif ağırlıkta olmalarına rağmen ısı transferinde etkili olmalarından dolayı özellikle uzay alanındaki uygulamalar da öne çıkmaktadırlar. Isı transferinde sağladığı önemli performans, 1sı borularının geniş bir kullanım alanı bulmasına sebep olmuş ve günümüze kadar gelişen ve yenilikçi teknoloji ile birçok farklı şekil ve forma dönüşmüştür. Elektronik devre elemanları, küçük bir hacim içinde sürekli isı üretimi oluşturmakta ve çok yüksek sıcaklıklara ulaşabilmektedir. Bu yüksek sıcaklıklar, elektronik devre elemanının bulunduğu elektronik sisteme ciddi hasarlara neden olabilmektedir. Dolayısıyla elektronik bileşenlerin ve sistemlerin, çalışma devamlılı̆̆ının korunabilmesi için, ısı enerjisinin çevreye verimli bir şekilde aktarılması ve sistemlerin güvenli çalışma sıcaklıklarına indirilmeleri gerekmektedir (Wang ve ark. 2015, Xie ve ark. 2020). Bu sebeple, bilgisayarların soğutulmasından uzay araçlarının termal kontrolüne kadar birçok uygulamada, sistemi soğutma ve güvenli çalışma sıcaklıklarında tutma işlemi için ısı boruları kullanılmaktadır.

Pratik uygulamalarda birçok farklı ısı borusu konfigürasyonu olduğu görülmektedir. Bu konfigürasyonlar 1sı borularının geometrik özellikleri ve çalışma parametreleri farklılaştırılarak oluşturulmaktadır. Bir 1sı pompasının tasarımı, fiziksel boyutlar, kanatçık eklentileri, tüp malzemesi, dönüş sayısı vb. gibi fiziksel parametreleri; tahliye basıncı, eğim, doluluk oranı, ısı girdisi vb. gibi çalışma parametrelerini içerebilmektedir. Ayrıca geleneksel çalışma akışkanları (su, metil alkol, etil alkol vb.) ve geleneksel olmayan çalışma akışkanları (nanoakışkanlar, soğutucu akışkanlar, vb.) gibi parametreleri barındırmaktadır. Özellikle son yıllarda, çeşitli çalışmalarda 1sı borusunun içine fitilli bir yapı eklentisi ve çalışma akışkanı olarak geleneksel olmayan nano akışkan kullanımı üzerine yoğunlaşılmaktadır. Bu çalışmalar, geleneksel olmayan akışkan kullanımının 1sı borusunun termal performansını etkilediğini göstermiştir. Günümüzde araştırmacılar, mikroelektronik teknolojisinin hızlı gelişmesi ve bu mikroelekronik devrelerin ısıl kontrolünde harici bir mekanik güç girişine ihtiyaç duyulmaması sebebiyle, 1sı borusu çalışmaları üzerine yoğunlaşmışlardır.

Literatür incelendiğinde, birçok araştırmacının (Çalışır ve ark. 2017, Wu ve ark. 2019, Masip ve ark. 2020 , Kilic 2018 vb.) yüksek sıcaklıklara ulaşan sistemlerin soğutulması için çapraz akışla soğutma, çarpan jetle soğutma vb. alternatif soğutma yöntemlerinin üzerinde çakıştıkları görülmüştür. Bu alternatif soğutma çalışmalarında, farklı geometriler ve farklı çalışma parametrelerinin üzerine yoğunlaşıldığı gözlemlenmiştir. Özellikle son yıllarda, nano partikül eklenmiş soğutucu akışkan kullanımının ısı transferini artırma özelliğinden faydalanan birçok yeni çalışmanın (Mahdavi ve ark. 2020, Ho ve ark. 2021, Kilic ve Muhammad 2018, Al-Rashed ve ark. 2016 vb.) yapıldığı görülmektedir. Ancak tüm bu soğutma yöntemlerinde fan benzeri ekstra sistem elemanlarına ihtiyaç duyulması bir dezavantaj oluşturmaktadır. Isı boruları yardımıyla yapılan soğutma da, sistem geometrisi çok basittir ve ekstra sistem elemanlarına ihtiyaç duyulmamaktadır. Isı boruları üzerine yapılan çalışmalar incelendiğinde, ilk çalışmaların 1960'lı yıllarda başladığı ve günümüze kadar birçok önemli çalışma yapıldığı gözlemlenmiştir. Yapılan bu çalışmalarda, incelenen 1sı borusundaki basınç ve sıcaklık dağılımının belirlenmesi, optimum 1sı borusu geometrisinin belirlenmesi ve 1sı transfer performansının geliştirilmesi üzerine yoğunlaşıldığı görülmektedir. Bu kapsamda, 1sı borusu çapı, dönüş sayısı, doluluk oranı, 1sı girdisi ve kullanılan akışkan tipi gibi parametrelerin değiştirilerek çalışmalar yapıldığı görülmektedir. Literatürde bulunan çalışmalardan bir kısmı aşağıda detaylı olarak verilmiştir.

Pachghare ve ark. (2014) 1sı borularının ısıl performans optimizasyonunun üzerine deneysel olarak çalışmışlardır. Çalışmalarında bakırdan yapılmış kapalı döngü titreşimli bir ısı borusunu (CLPHP) ele almışlardır. Bu kapsamda 20W ile 60W arasında değişen 1sı girdilerinde, çalışma akışkanını su, etanol, methanol, aseton, su-etanol, su-metanol ve su-aseton olarak değiştirerek ısıl performans üzerindeki etkileri incelemişlerdir. Deneylerinin sonucunda termal direncin, 40W 1sı girişine kadar sorunsuz bir şekilde azaldığını, ardından sabit kaldığını belirlemişlerdir. Su-aseton karışımlı çalışma sıvısının, ısı borusunda kullanılan diğer çalışma sıvılarının 
kullanımına göre 1sıl performans bakımından üstün olduğu sonucuna varmışlardır. Baitule ve ark. (2013) iki tur kapalı döngülü titreşimli bir ısı borusunun ısıl performans optimizasyonunu üzerine deneysel olarak çalışmışlardır. Kılcal bakır ısı boru üzerinde geçici ve sabit durum deneylerini gerçekleştirmişlerdir. $10 \mathrm{~W}$ ile $100 \mathrm{~W}$ arasında değișen farklı 1sı girdileri ve $\% 0$ ile $\% 100$ arasında değişen farklı dolum oranları için çalışmışlardır. Çalışma akışkanları olarak su, etanol, metanol ve aseton kullanmışlardır. Bu deneysel çalışmalar sonucunda, düşük ısıl direnç ve yüksek ısı transfer katsayısı olduğunda, \% 60 doluluk oranında daha iyi 1sı transfer özellikleri gösterdiğini gözlemlemişlerdir. Rahman ve ark. (2015) çalışmalarında, bakırdan yapılmış kapalı, 8 döngülü, titreşimli bir ısı borusunu (CLPHP) incelemişlerdir. Bu kapsamda, $0^{\circ}, 30^{\circ}$ ve $45^{\circ}$ eğim açısına sahip kanatlı ve kanatsız 1sı borusu geometrilerinin 1 sı transfer performansları üzerine yoğunlaşmışlardır. Sonuç olarak, çalışma akışkanı olarak etanol kullanımı, \% 50 doluluk oranı ve yoğuşturucu bölümünde dikey pozisyonda kanatçık kullanımı durumunda, 1sı borusunun daha iyi bir performans gösterdiğini gözlemlemişlerdir. Naik ve ark. (2012) tek tur kapalı titreşimli bakır bir ısı borusu için deneysel çalışmalar yapmışlardır. Deneylerini hem yatay hem de düşey yönlerde, \% 60 ve \% 80 farklı dolum oranları ve 1sı girdisi 9-15W arasında değişen koşullar için tekrarlamışlardır. Çalışma akışkanı olarak aseton, metanol ve etanolu kullanmışlardır. Sonuç olarak, çalışma akışkanı olarak aseton kullanıldığı, doluluk oranı \% 60 olduğu durumda, daha düşük ısıl direnç ve daha yüksek ısı transfer katsayısına ulaşıldığını gözlemlemişlerdir.

Clement ve ark. (2011), bakırdan yapılmış çapı $1,375 \mathrm{~mm}$ olan ve 15 turdan oluşan bir titreşimli ısı borusu üzerinde deneysel çalışmalar yapmışlardır. Bu kapsamda, çalışma akışkanı aseton, metanol ve su için, doluluk oranını \% 30-70 aralığında, 1sı girdilerini ise 80 ile $180 \mathrm{~W}$ arasında değiştirerek deneylerini tekrarlamışlardır. Bu çalışmanın sonucunda, metanolün \% 60 doluluk oranıyla aseton ve etanol ile karşılaştırıldığında daha iyi bir ısıl performans sergilediğini belirtmişlerdir. Geometrik yapının değiştirilmesinin, 1sı borularında 1sı transferi iyileştirmek için etkili bir yöntem olduğu Wang ve ark. (2018) ile Fertahi ve ark. (2018) tarafindan vurgulanmıştır. Wang ve ark. (2018), titreşimli bir 1sı borusu içerisindeki termal ve hidrodinamik davranışları analiz etmek için tasarladıkları bir 1sı borusu üzerinde çalışmışlardır. Çalışmalarında, 1sı borusunun ısıl performansını ANSYS-Fluent paket programını kullanarak sayısal olarak incelemişlerdir. Sonuç olarak, buharlaştırıcı ve yoğuşturucu konfigürasyonunda, kısmen yatay yapıya sahip 1sı borusunun kullanımının termal performansın artmasında etkili olduğunu belirtmişlerdir. Fertahi ve ark. ise (2018), kapalı döngülü bir 1sı borusunun termal performansını ve akış özelliklerini sayısal olarak analiz etmek için CFD simülasyonu gerçekleştirmişlerdir. Çalışmalarında, 1S1 borusunun içindeki akış yapısında düzensizlik yaratmak için, kesit değişimi (boru çapında daralmalar veya genişlemeler) veya kanatçıklar gibi çeşitli ısı transferi iyileştirmeleri yapılarak bir model oluşturmuşlardır. ANSYS-Fluent paket programını kullanarak ısıl performansı sayısal olarak incelemişlerdir. Çalışmalarının sonucunda, yoğuşturucu bölümünde eğimli kanatçık kullanımının 1sıl performansı artırdığını gözlemlemiş̧lerdir. Kumaer (2019), mikro kanallı yapıya sahip bir 1sı borusu içerisindeki akış ve ısıl performans optimizasyonunu belirlemek için yarı dairesel, dikdörtgen ve trapez tipteki mikro kanallı 1sı borusu üzerinde deneysel ve sayısal olarak çalışmışıtır. Sonuç olarak, trapez şekilli mikro kanalda 1sı transferinin yaklaşık olarak \% 12 arttığını gözlemlemiş ve sayısal çalışmasının sonuçlarını deneysel sonuçlar ile karşılaştırarak doğrulamıştır.

Pouryoussefi ve ark. (2017), buharlaştırıcı ve yoğuşturucu için sırasıyla $100-180^{\circ} \mathrm{C}$ ve $20-50{ }^{\circ} \mathrm{C}$ aralığında 2 boyutlu kapalı döngü titreşimli bir ısı borusundaki akışı sayısal olarak araştırmışlardır. Çalışmalarında Lyapunov üssü teorisini kullanmışlardır. Sonuçlarında Lyapunov üssünün, çoğunlukla düşük doluluk oranı için sıcaklığın artmasıyla yükseldiğini gözlemlemişlerdir. Ayrıca sonradan eklenen doluluk oranı ile bu pozitif değere karşılık gelen sıcaklık aralıklarının arttı̆̆ını göstermişlerdir. Wang ve ark. (2020), çalışmalarında farklı 1slatabilirliğe sahip su ile doldurulmuş 3 boyutlu bir ısı borusunu sayısal olarak incelemişlerdir. Çeşitli isı girişlerinde elde edilen termal performans verilerinin, hem yüzey 1slatabilirliğinden hem de 1sı giriş yüklerinden etkilendiği kanaatine varmışlardır. Düşük 1S1 akısı altında hidrofobik yüzeye sahip olan ısı borusunun hidrofilik yüzeye sahip olanlara göre daha düşük termal dirence sahip olduğunu belirtmişlerdir. Tersine durumda ise yüksek 1sı akısı altında hidrofilik yüzeye sahip olan 1sı borusunun hidrofobik yüzeye sahip olana göre daha iyi isıl performansa sahip olduğunu gözlemlemişlerdir. Gupta ve ark. (2019), sayısal çalışmalarında su ve $\mathrm{CeO}_{2} / \mathrm{H}_{2} \mathrm{O}$ nanoakışkanını çalışma akışkanı olarak kullanmışlardır. \%0,5, 1,0, ve 1,5 olmak üzere farklı hacimsel konsantrasyon oranları ve 10,15 ve $20 \mathrm{~kW} / \mathrm{m}^{2}$ olmak üzere farklı $1 s 1$ akıları için 2 boyutlu simülasyonlar yapmışlardır. Çalışmalarının sonucunda $\mathrm{CeO}_{2} / \mathrm{H}_{2} \mathrm{O}$ nano-akışkan kullanılan 1sı borusunun, su kullanılana göre daha iyi isıl performans sergilediğini belirlemişlerdir.

Yukarıda ki çalışmalardan da görüldüğü üzere, 1sı boruları termal kontrol sistemlerinde önemli bir rol üstlenmektedir. Ayrıca 1Sı transferinin olduğu birçok mühendislik uygulamasında karşımıza çıkabilmektedir. Bundan dolayı bu çalışmada, bir 1sı borusunun 1sıl performansını etkileyen önemli parametrelerden olan geometrik boyutlar, sınır şartları ve doluluk oranları değiştirilerek incelemeler yapılmıştır. Bu kapsamda bir ısı borusu, buharlaştırıcı bölümü, adyabatik bölüm ve yoğuşturucu bölümü olmak üzere 3 farklı bölüme ayılmış, bu bölümlerin farklı uzunlukları, 1sı borusunun farklı doluluk oranları ve farklı 1sı girdileri için analizler yapılmıştır. Bu parametrelerin 1sı borularının 1sıl performansına olan etkileri irdelenmiş ve incelenen 1sı borusunun optimum çalışma şartları tayin edilmeye çalışılmıştır.

\section{Model Geometrisi ve Matematiksel Formülasyon}

\subsection{Fiziksel Model ve Sistem Açıklaması}

$\mathrm{Bu}$ çalışmada kapalı döngülü bir 1sı borusu modeli kullanılmıştır. Bu kapsamda incelenen 1sı borusu için geliştirilen model geometrilerinin, temel bölümleri ve geometrik boyutları Şekil l'de şematik olarak verilmektedir. Şekilden de görüldüğü üzere incelenen 1Sı borusu bir buharlaştırıcıdan, bir yoğuşturucudan ve iki adet adyabatik bölümden oluşmaktadır. Isı borusunun temel bölümleri olan yoğuşturucu bölümünün, adyabatik bölümlerin ve buharlaştırıcı bölümünün uzunlukları değiştirilerek dört temel model geometri 
oluşturulmuştur. Bu kapsamda, buharlaştırıcı bölümün uzunluğu sabit tutularak, yoğuşturucu ve adyabatik bölümün farklı uzunlukları için incelemeler yapılmış̧ır. Yoğuşturucu bölüm ve orta adyabatik bölüm uzunluklarının birbirine oranı $\left(\mathrm{L}_{\mathrm{c}} / \mathrm{L}_{\mathrm{a} 1}\right)$ sırasıyla $0,5,1,1,25$ ve 2 olacak şekilde değiştirilerek model geometriler oluşturulmuştur.

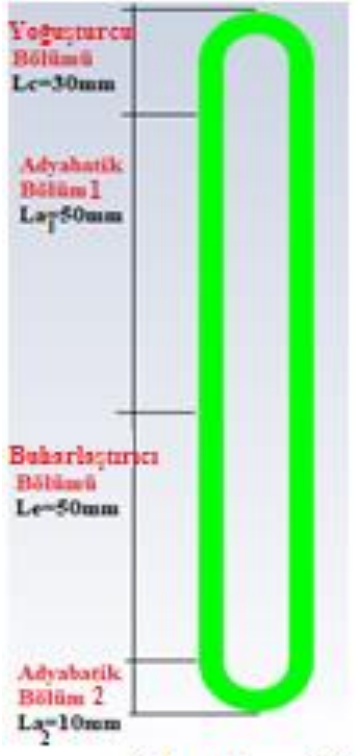

a) $\mathrm{L}_{\mathrm{c}} / \mathrm{L}_{\mathrm{al}}=0,5$

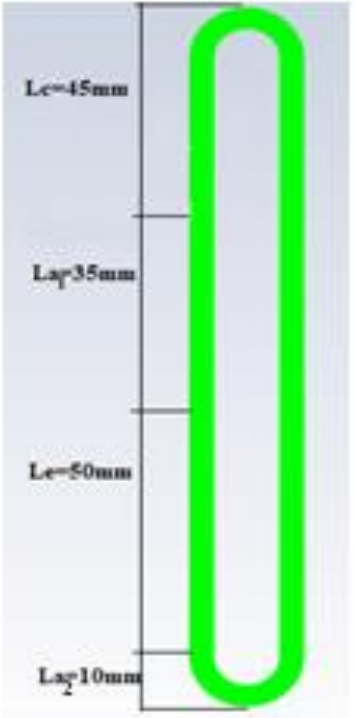

b) $\mathrm{L}_{\mathrm{c}} / \mathrm{L}_{\mathrm{al}}=1,0$

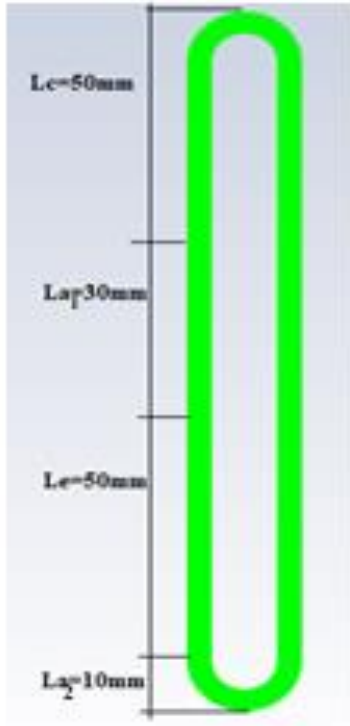

c) $\mathrm{L}_{\mathrm{c}} / \mathrm{L}_{\mathrm{al}}=1,25$

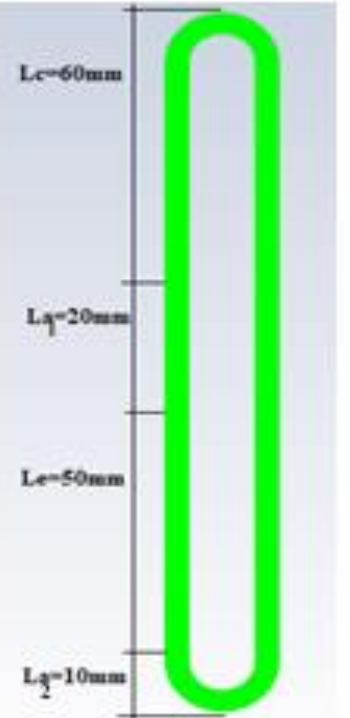

d) $\mathrm{L}_{\mathrm{c}} / \mathrm{L}_{\mathrm{al}}=2,0$

Şekil 1. Model geometrilerin şematik olarak gösterimi a)Model 1 b)Model 2 c)Model 3 d)Model 4

\subsection{Matematiksel Formülasyon}

Bu çalışmada iki fazlı akış için akışkan hacmi modeli (volume of fluid, VOF) kullanılarak incelemeler yapılmıştır. Bu kapsamda, akış içinde bulunan sıvı faz ile buhar fazın hacimsel oranı aşağıda ki gibi ifade edilmiştir. Burada $\alpha_{b}$ ve $\alpha_{s}$ sırasıyla akış içerisinde bulunan buhar fazın ve sıvı fazın hacimsel oranını temsil etmektedir. (Xie ve ark., 2020, Wang ve ark., 2015)

$$
\alpha_{b}+\alpha_{s}=1
$$

Akış içinde bulunan sıvı faz ve buhar faz için kütlenin korunumu denkleminin genel formu ayrı ayrı yazılabilir. Bu denklemlerde, $\mathrm{S}$ ve $\rho$ terimleri sırasıyla ilgili fazın kaynak terimini ve yoğunluğunu temsil etmektedir. (Xie ve ark., 2020, Wang ve ark., 2015)

$$
\begin{aligned}
& \frac{\partial \propto_{s}}{\partial t}+\nabla .\left(\propto_{s} \vec{v}\right)=\frac{s_{m, s}}{\rho_{s}} \\
& \frac{\partial \propto_{b}}{\partial t}+\nabla .\left(\propto_{b} \vec{v}\right)=\frac{s_{m, b}}{\rho_{b}}
\end{aligned}
$$

Sıvı hacmi modeline göre, momentum denkleminin genel formu ise aşağıda ki gibi yazılabilir (Xie ve ark., 2020, Wang ve ark., 2015). Burada $\rho$ akışın ortalama yoğunluğunu, $F$ ise yüzey gerilimini temsil etmektedir. F değeri, akışın buhar faz ve sıvı fazının hacimsel oranları ve yoğunluklarına bağlı olarak belirlenir.

$$
\frac{\partial}{\partial t}(\rho \vec{v})+\nabla \cdot(\rho \vec{v} \vec{v})=-\nabla P+\nabla\left[\mu\left(\nabla \vec{v}^{T}\right)\right]+\rho \vec{g}+\vec{F}
$$

İki fazdan oluşan akışın enerji denkleminin genel hali ise aşağıda verilmiştir (Xie ve ark., 2020, Wang ve ark., 2015). Burada E, P, $\lambda_{\text {eff }}$ ve $S_{h}$ terimleri sırasıyla akışın iç enerjini, basıncını, efektif ısıl iletkenliğini ve kaynak terimini temsil etmektedir.

$$
\frac{\partial}{\partial t}(\rho E)+\nabla \cdot(\vec{v}(\rho E+P))=\nabla \cdot\left(\lambda_{e f f} \nabla T\right)+S_{h}
$$

Kullanılan türbülans denklemlerinin genel hali ise aşağıdaki gibidir (Xie ve ark., 2020).

$$
\frac{\partial}{\partial t}(\rho k)+\frac{\partial}{\partial x_{i}}\left(\rho k u_{i}\right)=\frac{\partial}{\partial x_{j}}\left(\alpha_{k} \mu_{e f f} \frac{\partial k}{\partial x_{j}}\right)+G_{k}+G_{b}-\rho \varepsilon-Y_{M}+S_{k}
$$




$$
\frac{\partial}{\partial t}(\rho \varepsilon)+\frac{\partial}{\partial x_{i}}\left(\rho \varepsilon u_{i}\right)=\frac{\partial}{\partial x_{j}}\left(\alpha_{\varepsilon} \mu_{e f f} \frac{\partial \varepsilon}{\partial x_{j}}\right)+C_{1 \varepsilon} \frac{\varepsilon}{k}\left(G_{k}+C_{3 \varepsilon} G_{b}\right)-C_{2 \varepsilon} \rho \frac{\varepsilon^{2}}{k}-R_{\varepsilon}+S_{\varepsilon}
$$

Isı borularının 1sıl kapasitesi genellikle ısıl direnç ile tahmin edilir. Eşdeğer termal direnç, yoğuşturucu ile buharlaştırıcı arasındaki ortalama sıcaklık farkının termal yüklere bölünmesiyle elde edilir. Bu nedenle, eşdeğer ısıl direnç $\mathrm{R}_{\mathrm{th}}$ aşağıdaki denklemle ifade edilebilir.

$$
R_{t h}=\frac{T_{b}-T_{y}}{Q_{\text {giren }}}
$$

\subsection{Sınır Şartları}

Yukarıda verilen diferansiyel denklemlerin sayısal olarak çözülebilmesi için sınır şartlarına ihtiyaç duyulmaktadır. Bu çalışmada incelenen 1sı borusunun yoğuşturucu bölümü, adyabatik bölümleri ve buharlaştırıcı bölümünün yüzeylerine uygulanan sınır şartları aşağıda verilmiştir.

Buharlaştırıcı bölümünün yüzeylerine sabit 1sı akısı sınır şartı uygulanmıştır.

$$
-k \frac{\partial \mathrm{T}}{\partial \mathrm{n}}=q^{\prime \prime}
$$

Burada 1sı akısı q" aşağıdaki formül aracılığı ile hesaplanabilmektedir.

$$
q^{\prime \prime}=\frac{Q_{\text {giren }}}{A_{\text {buharlastrirc1 }}}
$$

Adyabatik bölümlerin yüzeylerinin yalıtıldığı ve adyabatik sınır şartı uygulandığı varsayılmıştır

$$
\frac{\partial \mathrm{T}}{\partial \mathrm{n}}=0
$$

Yoğuşturucu bölümünün yüzeylerine ise sabit $300 \mathrm{~K}$ sıcaklık sınır şartı uygulandığı düşünülmüştür.

$$
T_{\text {yoğușturucu }}=300 \mathrm{~K}
$$

Diferansiyel denklemler zamana bağlı olarak çözüleceğinden dolayı, başlangıç sınır şartı olarak sabit 293,15 K sıcaklık ve negatif çalışma basıncı uygulanmıştır.

\subsection{Sayısal Çözüm Yöntemi}

Bir 1sı borusunun 1sıl performansını önemli derecede yükseltebilmek için, 1sıl direncinin düşürülmesi gerekmektedir. Bunu sağlamanın bir yolu, farklı konfigürasyonlara sahip ısı borusu tasarımlarının deneysel düzenekler ile test edilerek optimum tasarım parametrelerinin belirlenmesidir. Bu kapsamda, güvenilir sonuçların bulunması açısından bu parametrelerin sonuca etkisinin hem eş zamanlı hem de birbirinden bağımsız olarak araştırılması gerekmektedir. Mümkün olabilecek tüm konfigürasyonların deneysel olarak test edilmesi hem zaman hem de maliyet açısından uygulanabilir olmadığından, bu çalışma kapsamında Hesaplamalı Akışkanlar Dinamiği prensibine dayanan sayısal yöntem ile çözüm yapılmıştır. Bu kapsamda, kullanılan sayısal çözüm yöntemi için aşağıda verilen sayısal metodoloji dikkate alınmıştır.

Bu çalışmada, incelenen ısı borusu içinde ki akış su ve su buharı olmak üzere iki fazdan oluşmaktadır. Bu fazların birbirine oranı ise zamanla anlık olarak değişiklik göstermektedir. Bu iki fazlı akışın sayısal olarak modellenebilmesi için, akışkan hacmi (Volume of Fluid, VOF) modeli kullanılmıştır. Bu kapsamda su baharı birincil faz, sıvı su ise ikincil faz olarak belirlenmiştir. Bu modelin alt yapısındaki süreklilik denklemleri, momentum korunum denklemleri, enerji korunum denklemleri ve türbülans denklemleri benimsenmiş ve sayısal olarak çözülmüştür. Akış sırasında gerçekleşen, yoğunlaşma ve buharlaşma olayları ise gelişmiş Lee modeli kullanılarak hesaba katılmıştır. Sıvı ve buhar arasındaki ara yüzeyde gözlemlenen yüzey gerilimleri için, sürekli yüzey kuvveti (Continuum Surface Force, CSF) modeli benimsenmiş ve yüzey gerilim değeri $F_{\mathrm{CSF}}=0.073 \mathrm{~N} / \mathrm{m}$ olarak, suyun temas açısı ise $20^{\circ}$ olarak belirlenmiştir (Wang ve ark. 2015). Sayısal çözüm yöntemi olarak SIMPLE algoritması tercih elde edilmiştir. Enerji ve momentum denkleminin ayrıklaştırılmasında Second order upwind metodu tercih edilmiştir. Basınç enterpolasyon şemasının çözümü için PRESTO yaklaşımı kullanılmıştır. Zaman adımından bağımsızlaştırma işlemi yapılarak, optimum zaman adımı $2 \times 10^{-4} \mathrm{~s}$ olarak belirlenmiştir.

\section{5. Ă (Mesh) yapısı}

Bu çalışmada incelenen modeller için ağ yapısı oluşturulurken, ssı borusunun yüzeylerine yakın bölgelere daha sık iç bölgelere ise daha seyrek bir ağ yapısı oluşturulmuştur. Kullanılan ağ yapısı yoğunluğunun, sayısal çözüm sonuçlarını etkilememesi amacıyla, sonuçları 
ağ yapısından bağımsızlaştırma işlemi yapılmıştır. Bu kapsamda, mevcut ısı borusu modeli için 9075, 18736, 34054 ve 106934 düğüm noktasına sahip dört farklı mesh yapısı oluşturularak, diğer tüm parametreler sabit kalması koşuluyla sayısal simülasyonlar tekrarlanmıştır. Oluşturulan ağ yapıları Şekil 2'de, elde edilen sonuçların karşılaştııılması ise Şekil 3'de verilmektedir.

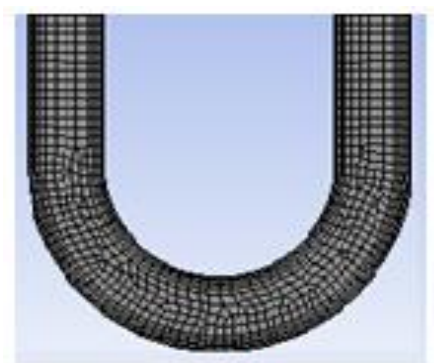

9075 düğüm

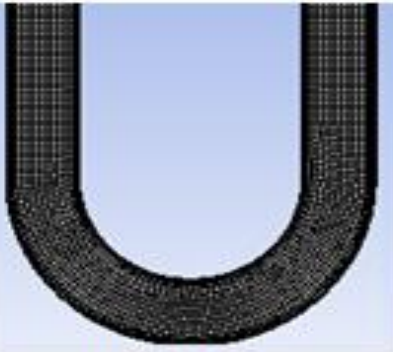

18736 düğüm

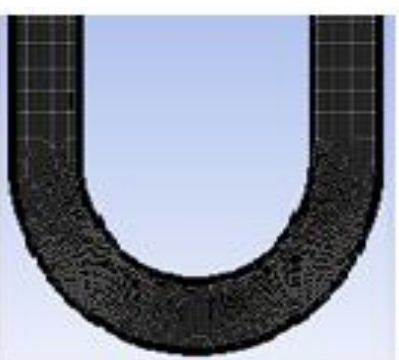

34054 düğüm

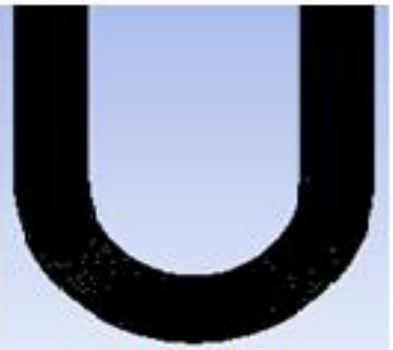

106934 düğüm

Şekil 2. Ağ yapılarının karşılaştırılması

Şekil 3 incelendiğinde, buharlaştırıcı sıcaklığı ve direncinin ağ yapısını oluşturan düğüm sayısı ile değişimi görülmektedir. 34054 ve 106934 düğüm nokta sayısına sahip ağ sistemleri için, elde edilen her iki sonucun da birbirine oldukça yakın değerde olduğu görülmektedir. Fazla düğüm sayısının, sayısal çözümde yapılan işlem sayısını ve çözüm süresini artıracağından dolayı 34054 düğüm sayısı için oluşturulan ağ yapısının, optimum ağ yapısı olarak kullanılabileceğine karar verilmiş ve bu çalışma sırasında yapılan tüm analizlerde ağ yapısı olarak kullanılmıştır.

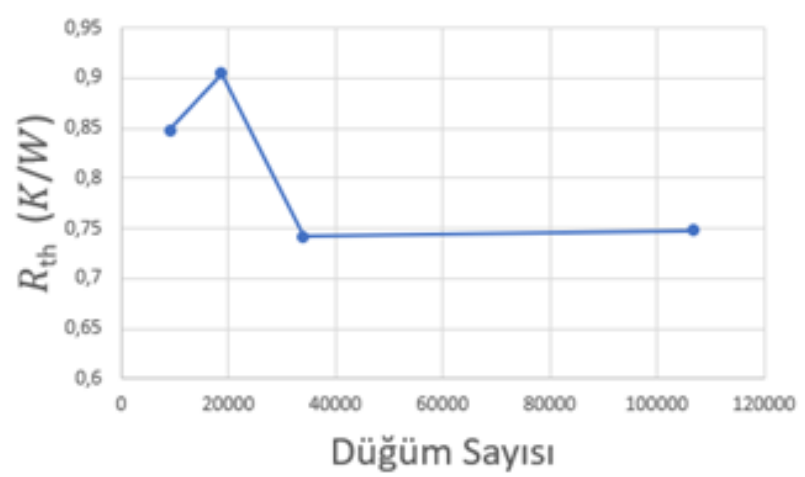

a)

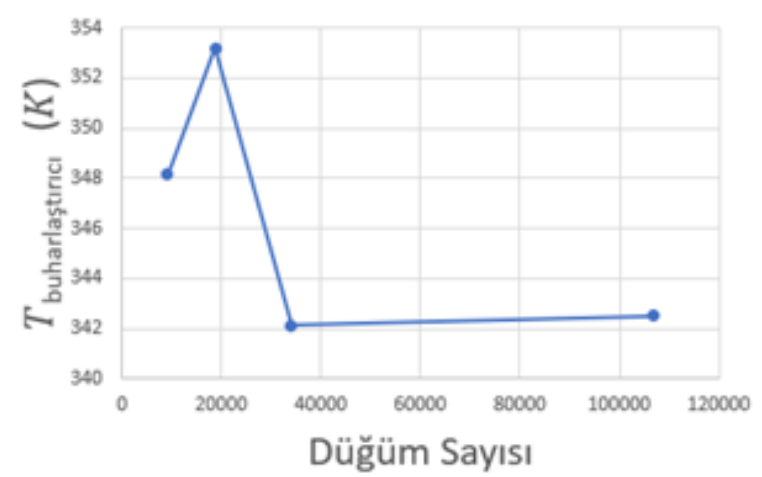

b)

Şekil 3. Farklı dügüm sayısına sahip ağ yapıları için elde edilen sonuçların karşılaştırılması

\subsection{Sayısal yöntemin güvenirliliğinin test edilmesi}

Bu çalışma sırasında kullanılan sayısal metodolojinin ve elde edilen sonuçların güvenilirliğini belirleyebilmek amacıyla, literatürde bulunan benzer bir çalışmanın geometrisi ve sınır şartları birebir kullanılarak sayısal çözüm yapılmış̧ır. Bu kapsamda literatürde bulunan Saha ve ark. (2014) tarafından yapılan deneysel bir çalışmanın geometrisi kullanılarak, \%60 doluluk oranı ve $18 \mathrm{~W}$ için simülasyon yapılmıştır. Bu simülasyon sonucu elde edilen sonuçlar ve diğer çalışmanın sonuçları Şekil 4'de birlikte verilmektedir. Şekil incelendiğinde, her iki çalışmadan elde edilen sonuçlar için çizilen eğrilerin birbiri ile oldukça uyumlu olduğu görülmektedir.

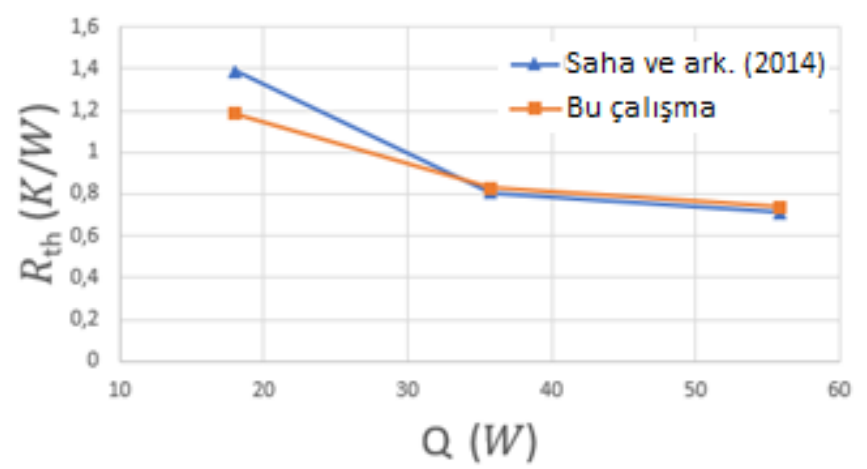

Şekil 4. Literatür sonuçları ile bu çalışmanın sonuçlarının karşılaştırılması 
Isı borularına etkiyen termal güçlerin artması, 1sı borularının termo hidrodinamiği üzerinde önemli bir etkiye sahip olan sıv1-buhar akış modellerinde değişikliklere neden olmaktadır. Bundan dolayı, bu çalışma sonucu elde edilen buhar hacim oranları için çizilen kontur grafikleri ile deneysel çalışmadan elde edilen görüntüler Şekil 5'de birlikte verilmiştir. Her iki çalışma sonuçları birlikte incelendiğinde, buhar kabarcıkların büyüklüğ̈nün ve yerinin birbirleri ile oldukça uyumlu olduğu görülmektedir. Şekil 4 ve Şekil 5 birlikte değerlendirildiğinde, bu çalışmada kullanılan sayısal yöntemin ve elde edilen sonuçların güvenilebilir bir seviyede olduğu söylenebilir.

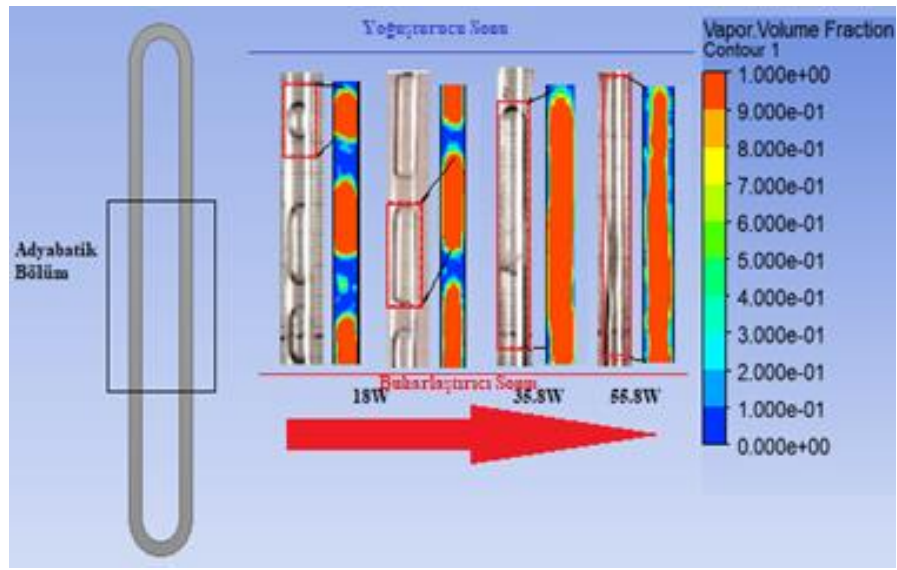

Şekil 5. Literatür (Saha ve ark.,2014) ve bu çalışma için buhar hacim oranının karşılaştırılması

\section{Bulgular ve Tartışmalar}

Bu çalışma kapsamında incelenen ısı borusunun $4 \mathrm{~mm}$ çapa sahip bakır bir borudan yapıldığı varsayılmıştır. Yapılan tüm analizlerde yoğuşturucu sıcaklığı $300 \mathrm{~K}$, buharlaştırıcı uzunluğu $50 \mathrm{~mm}$, çalışma akışkanı ise su olacak şekilde sabit olarak belirlenmiştir. Isı borusunun buharlaştırıcı kısmı aşağıda olacak şekilde dikey konumda durduğu düşünülmüştür. Isı girdileri $10 \mathrm{~W}$ ile $80 \mathrm{~W}$ arasında, doluluk oranı ise $\% 40$ ile $\% 80$ arasında değiştirilmiştir. Yoğuşturucu bölüm ve ortadaki adyabatik bölümün uzunluklarının oranı $\left(\mathrm{L}_{\mathrm{c}} / \mathrm{L}_{\mathrm{a} 1}\right)$ 0,5, 1, 1,25 ve 2 olacak şekilde model geometriler oluşturularak, 1sı borusunun akış ve 1sıl karakteristikleri incelenmiştir. İki fazlı akış şartları için, zamana bağlı çözüm yapılarak ilk 20 saniye için çözümler irdelenmiştir. Elde edilen veriler aracılığı ile, çalışılan parametre aralığında incelenen $1 s ı$ borusunun akış karakteristikleri ve ısıl performansı belirlenmeye çalışılmıştır. Bu amaçla çizilen bazı grafikler aşağıda irdelenmiştir.

$\mathrm{L}_{\mathrm{c}} / \mathrm{L}_{\mathrm{a} 1}=1$ ve doluluk oranı \%50 olduğu durumda, 1sı borusunun içindeki sıcaklık dağılımının, hız dağılımının ve su hacim oranının giren 1sı miktarı ile değişimi sırasıyla Şekil 6'nın şıklarında verilmektedir. Şekil 6a incelendiğinde, 1Sı borusunun buharlaştırıcı bölümünden giren 1sı miktarı arttıkça, 1sı borusu içindeki akışkanın sıcaklık değerlerinin de arttı̆̆ görülmektedir. Özellikle $80 \mathrm{~W}$ değerinde oldukça yüksek sıcaklıklar gözlemlenmiştir. Benzer olarak Şekil 6b'de de görüldüğü üzere, giren 1sı miktarı arttıkça, akışkanın hızı da artmaktadır. Isı borusu içinde bölgesel sıcaklık farkı arttıkça, oluşan yoğunluk farkından dolayı akışkanın hızı da artış göstermektedir. Ayrıca giren ısı miktarının artması ile 1sı borusu içinde ki su ve buhar dengesinin değiştiği gözlemlenmiştir.

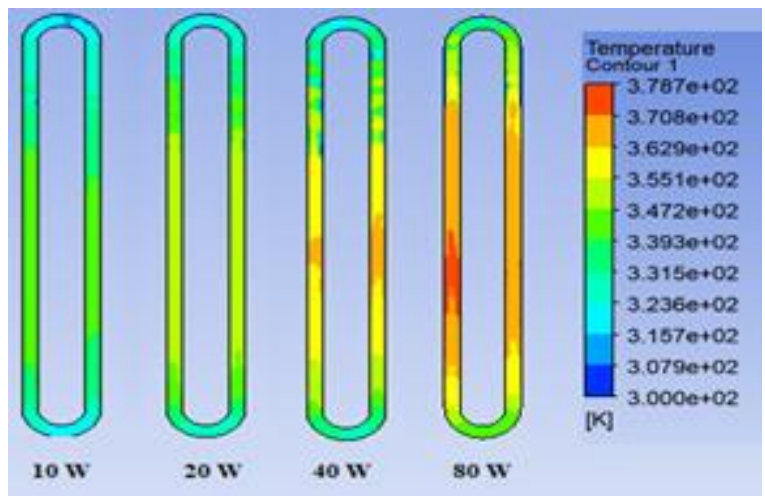

a)

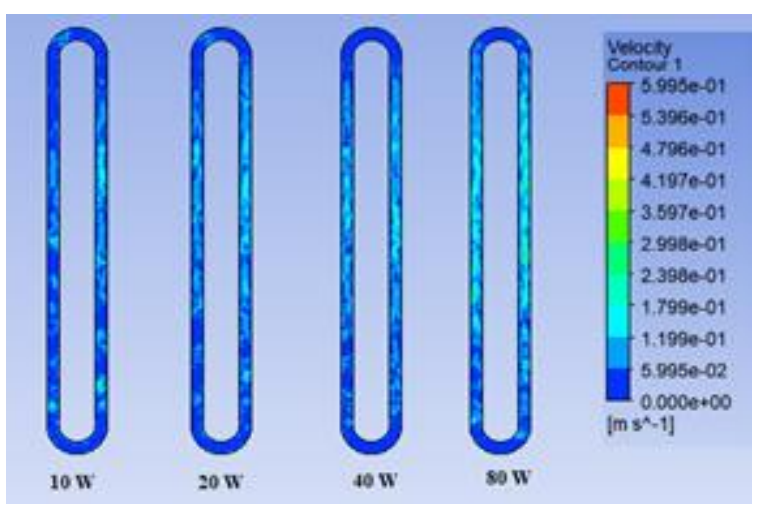

b) 


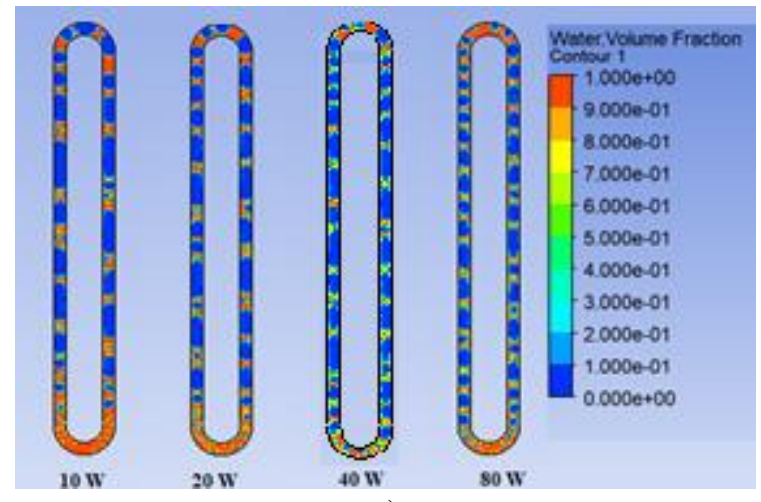

c)

Şekil 6. $\mathrm{L}_{\mathrm{c}} / \mathrm{L}_{\mathrm{a} 1}=1$ ve doluluk oranı $\% 50$ olduğu durumda, farklı 1s1 girdileri için kontur gösterimleri a) Sicaklık b) Hiz c) Su hacim oranı

Doluluk oranı \% 50 olduğu durumda, farklı $\mathrm{L}_{\mathrm{c}} / \mathrm{L}_{\mathrm{a} 1}$ oranları için, 1sıl direnç ve buharlaştırıcı sıcaklık değerlerinin giren 1sı miktarı ile değişimi sırasıyla Şekil 7a ve Şekil 7b'de verilmektedir. Şekillerden de görüldüğü üzere, tüm $\mathrm{L}_{\mathrm{c}} / \mathrm{L}_{\mathrm{a} 1}$ oranları için 1sı borusuna giren $1 S 1$ miktarının artması ile 1sıl direnç değeri azalış göstermektedir. Isıl dirençte görülen bu azalış, giren 1sı miktarı arttıkça 1sı borusunun 1sıl performansının attığını belirtmektedir. Ancak, tüm $\mathrm{L}_{\mathrm{c}} / \mathrm{L}_{\mathrm{a} 1}$ oranları için 1sı borusuna giren 1Sı miktarının artması ile buharlaştırıcı sıcaklığının da arttığı görülmektedir.

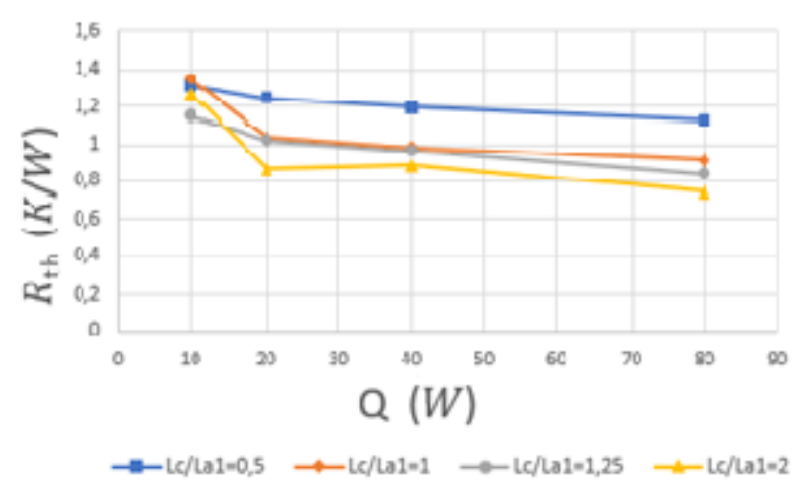

a)

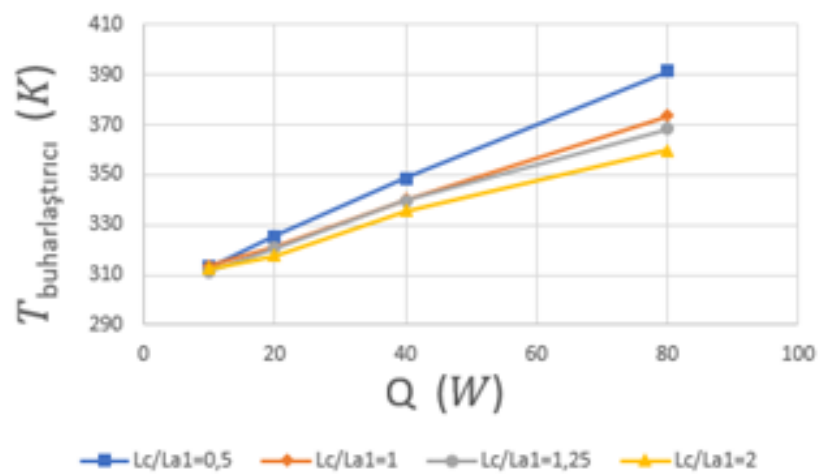

b)

Şekil 7. Doluluk oranı \% 50 olduğu durumda, farklı $\mathrm{L}_{\mathrm{c}} / \mathrm{L}_{\mathrm{a}}$ oranları için (a) 1sıl direnç ve (b) buharlaştırıcı sıcaklık değerlerinin giren 1sı ile değişimi

Giren 1S1 $40 \mathrm{~W}$ ve doluluk oranı $\% 50$ olduğu durumda, ısı borusunun içindeki sıcaklık dağılımının, hız dağılımının ve su hacim oranının $\mathrm{L}_{\mathrm{c}} / \mathrm{L}_{\mathrm{a} 1}$ oranı ile değişimi sırasıyla Şekil 8'in şıklarında verilmektedir. Şekil incelendiğinde, 1sı borusunun $\mathrm{L}_{\mathrm{c}} / \mathrm{L}_{\mathrm{a} 1}$ oranı artırıldığında sıcaklık değerlerinin azaldığı görülmektedir. Bu durumun yoğuşturucu uzunluğunun artmasından dolayı 1Sı borusundan atılan 1S1 miktarının artması ile gerçekleştiği söylenebilir. Farklı $\mathrm{L}_{\mathrm{c}} / \mathrm{L}_{\mathrm{a} 1}$ oranları için çizilen hız dağılımları incelendiğinde ise, $\mathrm{L}_{\mathrm{c}} / \mathrm{L}_{\mathrm{a} 1}$ oranı arttıkça akışkan hızının azaldığı görülmektedir. Ayrıca yoğuşturucu uzunluğu arttıkça, 1sı borusu içerisindeki su buharı oranın azaldığı belirlenmiştir.

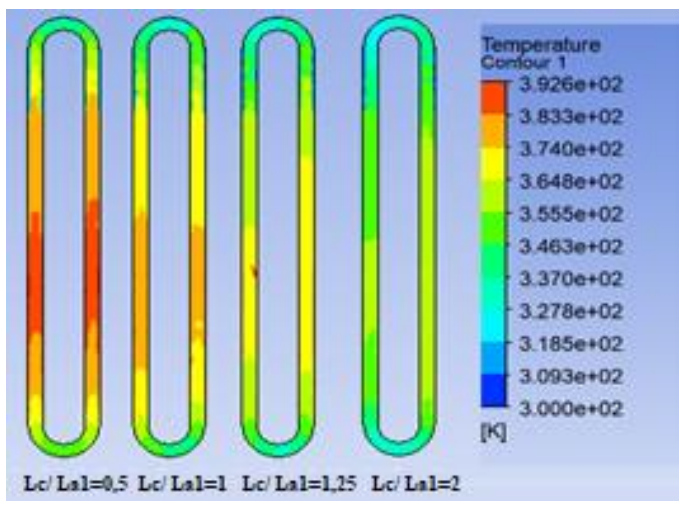

a)

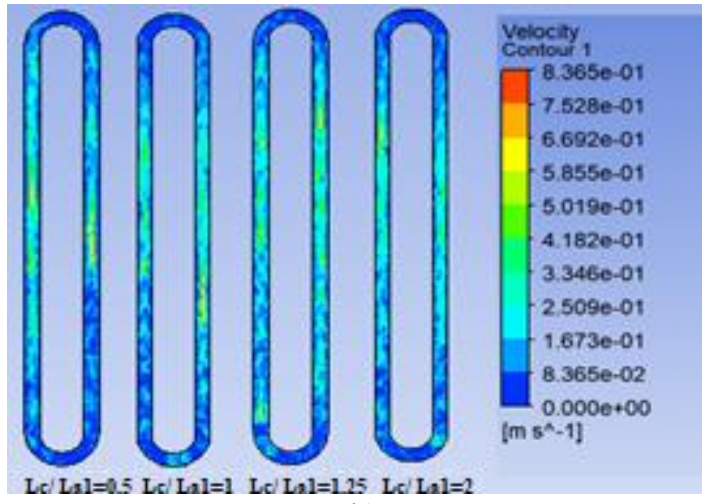

b) 


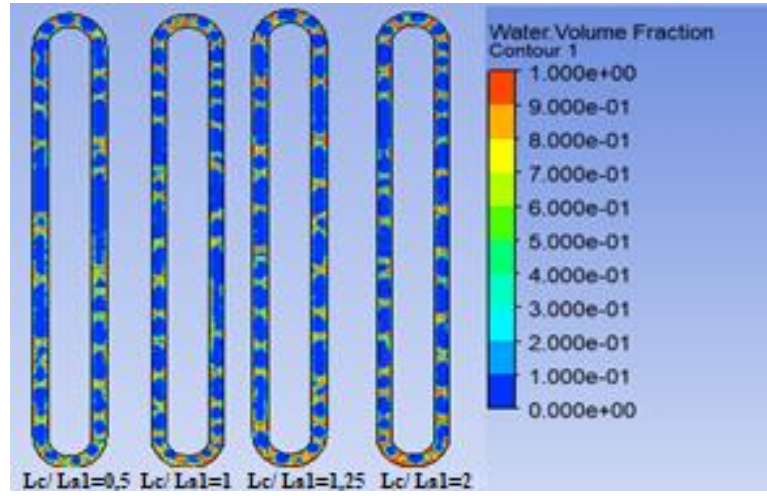

c)

Şekil 8. Giren $1 \mathrm{~S} 140 \mathrm{~W}$ ve doluluk oranı $\% 50$ olduğu durumda, farklı $\mathrm{L}_{\mathrm{c}} / \mathrm{L}_{\mathrm{a} 1}$ oranları için kontur gösterimleri a) Sicaklık b) Hız c) Su hacim oranı

Doluluk oranı \% 50 olduğu durumda, farklı giren 1sı miktarları için, 1sıl direnç ve buharlaştırıcı sıcaklık değerlerinin giren 1Sı miktarı ile değişimi sırasıyla Şekil 9a ve Şekil 9b'de verilmektedir. Şekiller incelendiğinde yüksek giren 1sı miktarları için, $\mathrm{L}_{\mathrm{c}} / \mathrm{L}_{\mathrm{a} 1}$ oranının artması ile 1sıl direnç değerinin ve buharlaştırıcı sıcaklığının azaldığı görülmektedir. Ancak giren 1sı miktarı 10W için, hem 1sıl direnç değerinin hem de buharlaştırıcı sıcaklık değerinin, $\operatorname{artan} \mathrm{L}_{\mathrm{c}} / \mathrm{L}_{\mathrm{a} 1}$ oranından pek etkilenmediği gözlemlenmiştir.

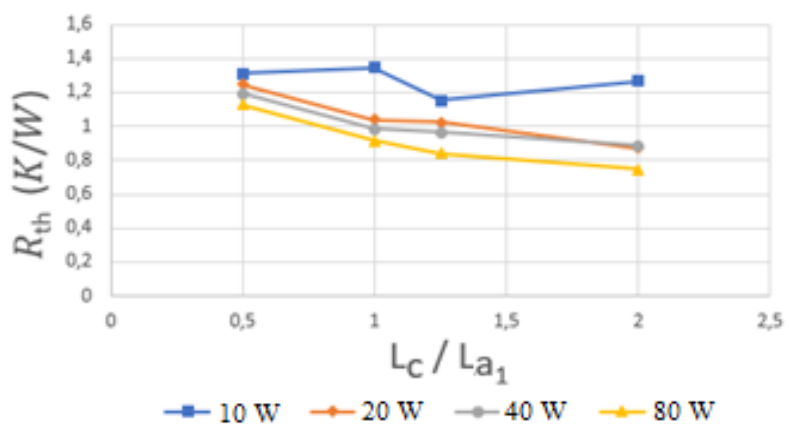

a)

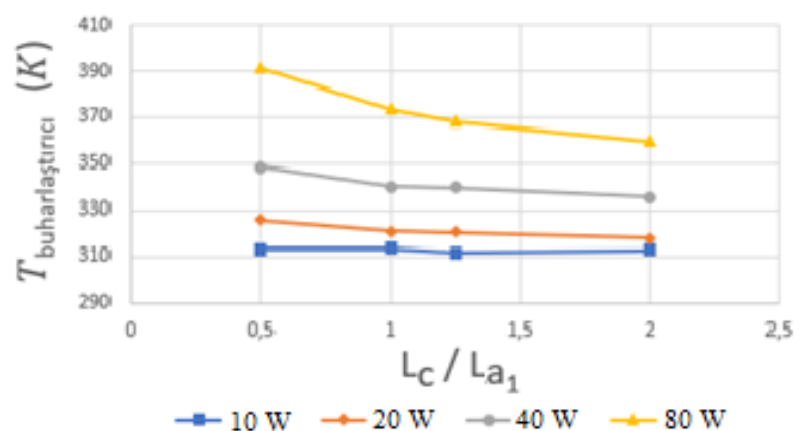

b)

Şekil 9. Doluluk oranı \%50 olduğu durumda, farklı giriş ısıları için (a) 1sıl direnç ve (b) buharlaştırıcı sıcaklık değerlerinin $\mathrm{L}_{c} / \mathrm{L}_{\mathrm{a}}$ oranları ile değişimi

Şekil 10'da ise $\mathrm{L}_{\mathrm{c}} / \mathrm{L}_{\mathrm{a} 1}=1$ ve giren 1sı miktarı $40 \mathrm{~W}$ olduğu durumda, \%40 ile \%80 doluluk oranı arasında değişen dört farklı doluluk oranını için, ısı borusunun sıcaklık dağılımı, hız dağılımı ve su hacim oranının değişimi görülmektedir. Şekil incelendiğinde, doluluk oranı \%40 için buharlaştırıcı sıcaklığının maksimum seviyede olduğu görülmüştür. Ancak \%50 doluluk oranları için sıcaklık değerleri aniden düş̧mektedir. Diğer parametreler sabit iken, 1sı borusunun doluluk oranının \%50 değerinden artırılması ile sıcaklık ve hız değerlerinin azaldığı belirlenmiştir. Ayrıca doluluk oranının artması ile 1sı borusu içinde ki su ve buhar dengesinin değiştiği gözlemlenmiştir.

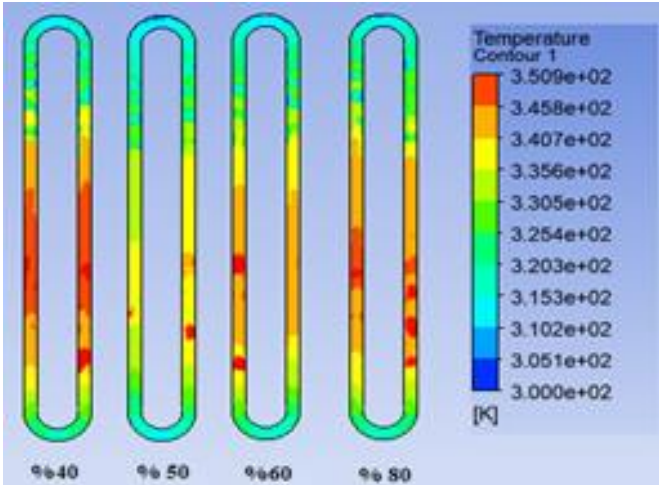

a)

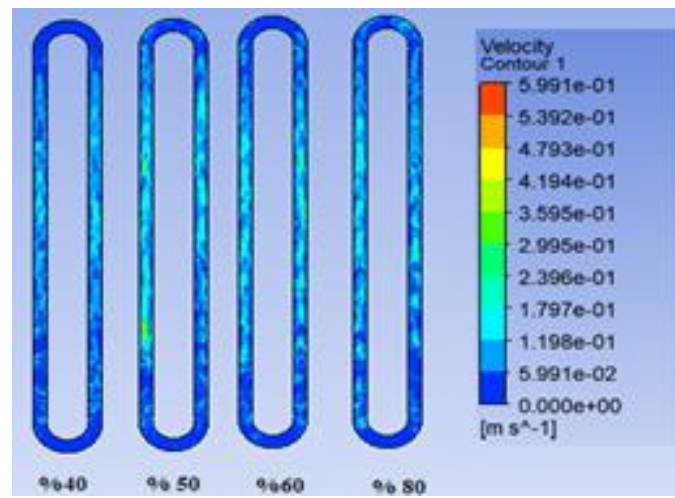

b) 


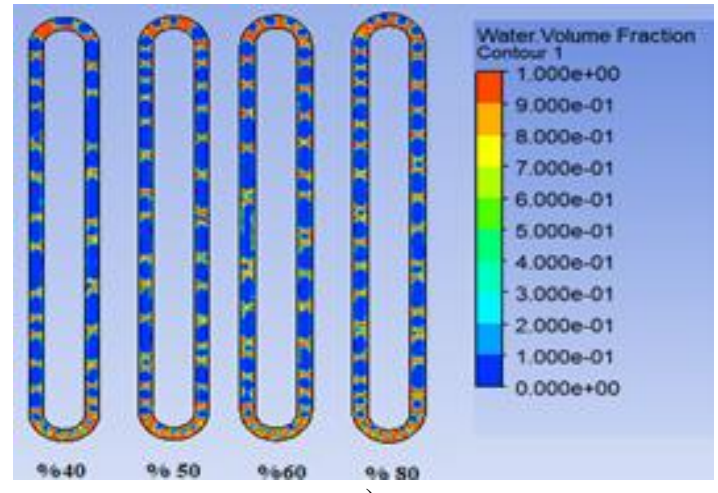

c)

Şekil 10. $\mathrm{L}_{\mathrm{c}} / \mathrm{L}_{\mathrm{a} 1}=1$ ve 1Sı girdisi $40 \mathrm{~W}$ olduğu durumda, farklı doluluk oranları için kontur gösterimleri a) Sicaklık b) Hız c) Su hacim oranı

Şekil 11'de $\mathrm{L}_{\mathrm{c}} / \mathrm{L}_{\mathrm{a} 1}=1$ ve giren 1S1 $40 \mathrm{~W}$ olduğu durumda, 1sıl direnç ve buharlaştırıcı sıcaklığının doluluk oranları ile değişimi görülmektedir. Şekillerden de görüldüğü üzere, doluluk oranı $\% 40$ olduğu durumda hem 1sıl direnç hem de buharlaştırıcı sıcaklığı maksimum değerdedir. Ancak doluluk oranının \%50'ye çıkması ile bu iki değerde de ani bir düşüş gerçekleşmekte ve minimum seviyeye inmektedir. Doluluk oranı artmaya devam ettikçe, hem 1sıl direnç hem de buharlaştırıcı sıcaklığı artış göstermektedir. Dolayısıyla, doluluk oranının değiş̧imi ile ısıl direncin ve buharlaştırıcı sıcaklı̆̆ının değişiminin benzer bir davranış gösterdiği söylenebilir. İncelenen doluluk oranlarında, 1sı direncinin en düşük olduğu \%50 doluluk oranının, 1sı borusunun soğutma performan S1 açısından optimum doluluk oranı olduğu görülmektedir.

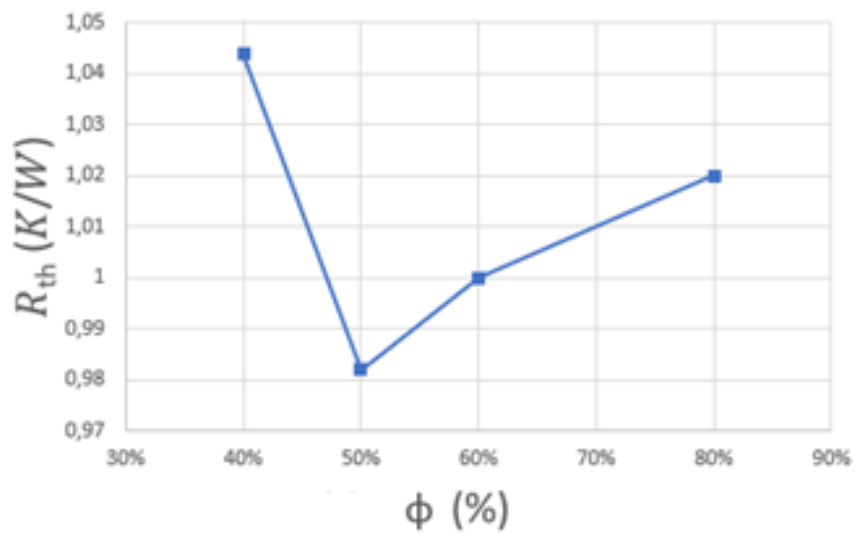

a)

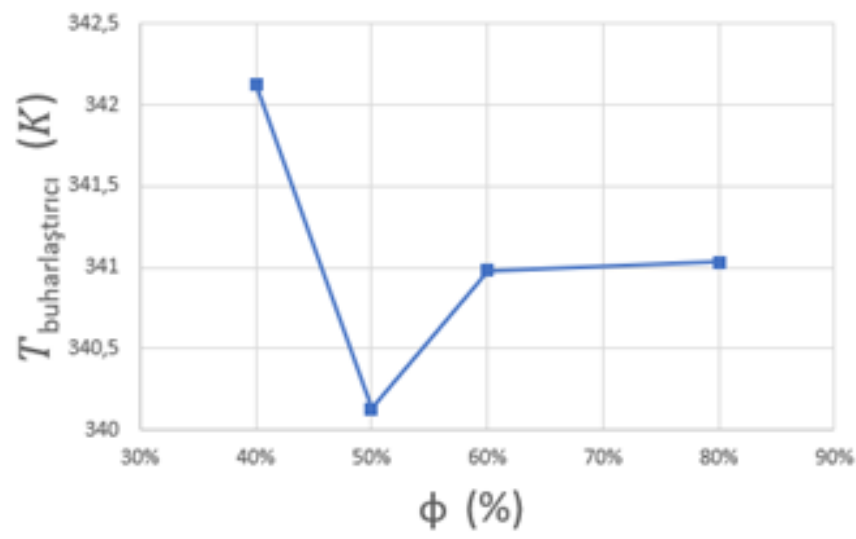

b)

Şekil 11. $\mathrm{L}_{\mathrm{c}} / \mathrm{L}_{\mathrm{a} 1}=1$ ve giren 1s1 $40 \mathrm{~W}$ olduğu durumda, (a) 1sıl direnç ve (b) buharlaştırıcı sıcaklık değerlerinin doluluk oranları ile değişimi

Doluluk oranı $\% 50$ ve giren $1 \mathrm{~s} 140 \mathrm{~W}$ olduğu durumda faklı $\mathrm{L}_{\mathrm{c}} / \mathrm{L}_{\mathrm{a} 1}$ oranları için, ssıl direnç ve buharlaştırıcı sıcaklık değerlerinin zaman ile değişimi sırasıyla Şekil 12a ve Şekil $12 b$ 'de verilmektedir. Şekiller incelendiğinde, tüm $\mathrm{L}_{\mathrm{c}} / \mathrm{L}_{\mathrm{a} 1}$ oranları için 1 sıl direnç ve buharlaştırıcı sıcaklık değerlerinin zaman ile değişiminin benzer bir profil sergilediği görülmektedir. Genel olarak, $\mathrm{L}_{\mathrm{c}} / \mathrm{L}_{\mathrm{a} 1}$ oranı 0,5 için çizilen eğri en üste yer almaktadır. $\mathrm{L}_{\mathrm{c}} / \mathrm{L}_{\mathrm{a} 1}$ oranı arttıkça çizilen eğriler ise daha aşağıda yer almaktadır. Tüm $\mathrm{L}_{\mathrm{c}} / \mathrm{L}_{\mathrm{a} 1}$ oranları için, hem 1sıl direnç hem de buharlaştırıcı sıcaklık değerinde yaklaşık olarak 5. saniyeye kadar lineer bir artış gözlemlenmektedir. Bu andan sonra zamanın ilerlemesi ile, artış miktarı azalmakla birlikte yaklaşık 12. saniyeye kadar artış sürmektedir. 12. saniyeden sonra ise önemli bir değişim görülmemektedir. Dolayısıyla bu çalışmada incelenen parametre aralığında, 1sı borusunun kararlı hale gelme süresinin yaklaşık olarak 12s olduğu söylenebilir. 


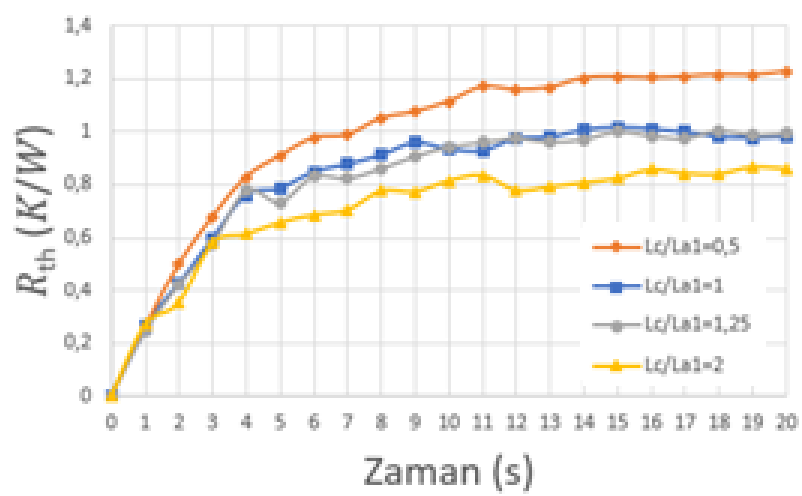

a)

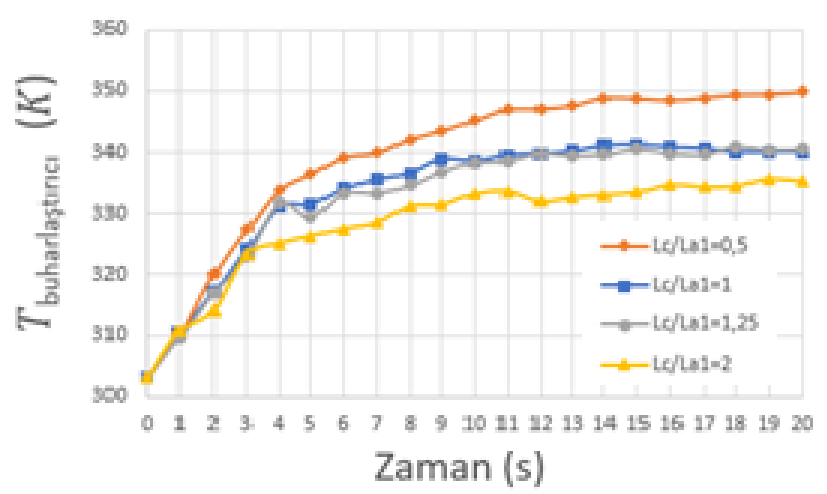

b)

Şekil 12. Doluluk oranı \% 50 ve giren $1 \mathrm{~s} 140 \mathrm{~W}$ olduğu durumda, faklı $\mathrm{L}_{\mathrm{c}} / \mathrm{L}_{\mathrm{a} 1}$ oranları için (a) 1sıl direnç ve (b) buharlaştırıcı sıcaklık değerlerinin zaman ile değişimi

\section{Sonuç}

$\mathrm{Bu}$ çalışma kapsamında, bakır bir borudan yapılan kapalı döngülü bir ısı borusunun 1sıl performansı sayısal olarak incelenmiştir. Bu amaçla, farklı model geometrileri, farklı ısı girdileri ve farklı doluluk oranları için iki fazlı akış şartlarında, üç boyutlu ve zamana bağımlı olarak sayısal analizler yapılmıştır. Elde edilen veriler aracılığı ile, çalışılan parametre aralığında incelenen isı borusunun akış karakteristikleri ve 1 sıl performansı belirlenmeye çalışılmıştır. Yapılan analizler sonucunda, diğer parametreler sabit iken 1sı borusunun buharlaştırıcı bölümünden giren 1sı miktarı arttıkça, 1sı borusu içindeki akışkanın sıcaklık ve hız değerlerinin arttığ 1sıl direncinin ise azaldığı belirlenmiştir. $\mathrm{L}_{\mathrm{c}} / \mathrm{L}_{\mathrm{a}}$ oranının artması ile ise, 1sıl direnç değerinin ve buharlaştırıcı sıcaklığının azaldığı tespit edilmiş̧tir. Isı borusunun doluluk oranı $\% 40$ olduğu durumda, hem 1sıl direnç hem de buharlaştırıcı sıcaklığının maksimum değerde olduğu belirlenmiştir. Ancak doluluk oranının \%50'ye çıkması ile bu iki değerde de ani bir düşüş gerçekleşerek minimum seviyeye indiği gözlemlenmiştir. Isı borusunun ısıl direnç ve buharlaştırıcı sıcaklık değerlerinin zamanla arttığı, ancak yaklaşık olarak 12. saniyeden sonra kararlı hale geldiği belirlenmiştir. Sonuç olarak, bir 1sı borusunun yoğuşturucu uzunluğunun artırılmasının 1sıl performansı olumlu yönde etkilediği, 1sı borusunun doluluk oranı \%50 olduğu durumda ise optimum 1sıl performans sağlandığı söylenebilir. Yapılan literatür incelemesinde ısı borularının soğutma performansının artırılması üzerine yapılan yeni çalışmalara ihtiyaç olduğu görülmüştür. Bundan dolayı bu çalışmanın çıktılarının, gelecekte yapılacak yeni çalışmalara destek olabileceği, 1sı borularının aktif olarak kullanıldığı uzay araçları, haberleşme uyduları, askeri sistemler vb. gibi kritik mühendislik uygulamalarının geliştirilmesine fayda ve bilgi sağlayabileceği umut edilmektedir.

\section{Referanslar}

Al-Rashed, M.H., Dzido G., Korpyś M., Smołka J., Wójcik J. (2016), Investigation on the CPU nanofluid cooling, Microelectronics Reliability, 63, 159-165.

Baitule D. A., Pachghare P. R. (2013), Experimental analysis of closed loop pulsating heat pipe with variable filling ratio. International Journal Mechanical Engineering and Robotics Research 2, No 3

Clement J. and Wang X. (2011), Experimental investigation of pulsating heat pipe performance with regard to fuel cell cooling application, Applied Thermal Engineering, 50, 268-274

Çalışır T., Çalışkan S., Kılıç M., Başkaya Ş. (2017), Çarpan akışkan jetleri kullanarak kanatçıklı yüzeyler üzerindeki akış alanının sayısal olarak incelenmesi, Gazi Üniversitesi Mühendislik Mimarlık Fakültesi Dergisi, 32, 127-138

Fertahi S.D., Bouhal T., Agrouaz Y., Kousksou T., Rhafiki T.E., Zéraouli Y. (2018), Performance optimization of a two-phase closed thermosyphon through cfd numerical simulations, Applied Thermal Engineering, 128, 551-563

Gupta N.K., Barua A., Mishra S., Singh S.K., Tiwari A.K., Ghosh S. K. (2019), Numerical study of CeO2 /H2O nanofluid application on thermal performance of heat pipe, Materials Today: Proceedings, 18, 1006-1016

Ho C.J., Cheng C.Y., Yang T.F., Rashidi S., Yan W.M. (2021), Experimental study on cooling performance of nanofluid flow in a horizontal circular tube, International Journal of Heat and Mass Transfer, 169, 120961.

Kilic M. (2018), A numerical analysis of transpiration cooling as an air cooling mechanism, Heat Mass Transfer, 54, 3647-3662 
Kilic M., Muhammad A.H. (2019), Numerical investigation of combined effect of nanofluids and multiple impinging jets on heat transfer, Thermal Science, 23 (5B), 3165-3173.

Kumaer P. (2019), Numerical investigation of fluid flow and heat transfer in trapezoidal microchannel with groove structure, International Journal of Thermal Science, 136, 33-43

Lin Z.R., Wang S.F., Chen J.J. (2011), Experimental study on effective range of miniature oscillating heat pipes, Applied Thermal Engineering, 31(5), 880-886

Mahdavi M., Sharifpur M., Meyer J.P. (2020), Fluid flow and heat transfer analysis of nanofluid jet cooling on a hot surface with various roughness, International Communications in Heat and Mass Transfer,118, 104842.

Masip Y., Campo A., Nunez S.M. (2020), Experimental analysis of the thermal performance on electronic cooling by a combination of cross-flow and an impinging air jet, Applied Thermal Engineering, 167, 114779

Naik R., Varadarajan V., Pundarika G., Narasimha K. R. (2013), Experiment investigation and performance evaluation of a Closed loop PHP, Journal of Applied Fluid Mechanics, 6(2), 267-275

Noori S.M.A., Abadi R, Meyer J.P., Dirker J. (2018), Numerical simulation of condensation inside an inclined smooth tube, Chemcial Engineering Science, 182, 132-145

Pachghare P. R., Mahalle A. M. (2014), Thermo-hydrodynamics of closed looppulsating heat pipe: an experimental study. In No 33873394 India

Pouryoussef S.M., Zhang Y. (2017), Analysis of chaotic flow in a 2D multi-turn closed-loop pulsating heat pipe, Applied Thermal Engineering, 126, 1069-1076

Rahman M. L., Sultan R. A., Islam T., Noor M. H., Mohammad A. (2015), An experimental investigation on the effect of fin in the performance of closed loop pulsating heat pipe. In No.1216 Bangladesh

Saha N., Das P.K., Sharma P. (2014), Influence of process variables on the hydrody- namics and performance of a single loop pulsating heat pipe, International Journal Heat Mass Transfer, 74, 238-250

Wang J., Bai X. (2018), The features of clphp with partial horizontal structure, Applied Thermal Engineering, 133, 682-689

Wang J., Ma H., Zhu Q. (2015), Effects of the evaporator and condenser length on the performance of pulsating heat pipes, Applied Thermal Engineering, 91, 1018-1025

Wang J., Xie J., Liu X. (2020), Investigation of wettability on performance of pulsating heat pipe, International Journal of Heat and Mass Transfer, 150, 119354

Wu R., Hong T., Cheng Q., Zou H., Fan Y., Luo X. (2019), Thermal modeling and comparative analysis of jet impingement liquid cooling for high power electronics, International Journal of Thermal Science (137) 42-51

Xie F., Li X., Qian P., Huang Z., Liu M. (2020), Effects of geometry and multisource heat input on flow and heat transfer in single closed-loop pulsating heat pipe, Applied Thermal Engineering (168) 114856 